\title{
Patient Characteristics and Determinants of CD4 at Diagnosis of HIV in Mexico from 2008 to 2017: A 10-Year Population-Based Study
}

Amilcar Azamar Alonso ( $\sim$ azamaraa@mcmaster.ca )

McMaster University

Sergio A Bautista-Arredondo

National Institute of Public Health, Mexico

Fiona Smaill

McMaster University, Hamilton, Ontario, Canada

Lawrence Mbuagbaw

McMaster University ON

Andrew P Costa

McMaster University

Jean-Eric Tarride

McMaster University

Research

Keywords: HIV, Late diagnosis, Mexican SALVAR

Posted Date: November 13th, 2020

DOI: https://doi.org/10.21203/rs.3.rs-104632/v1

License: () (1) This work is licensed under a Creative Commons Attribution 4.0 International License.

Read Full License 
Title: Patient characteristics and determinants of CD4 at diagnosis of HIV in Mexico

3 from 2008 to 2017: a 10-year population-based study

4

5 Amilcar Azamar-Alonso, $\mathrm{PhD}(\mathrm{c})^{12}$, Sergio A. Bautista-Arredondo, $\mathrm{MSc}^{3}$, Fiona Smaill,

$6 \mathrm{MB}^{4}$, Lawrence Mbuagbaw, MD, MPH, $\mathrm{PhD}^{56}$, Andrew P Costa, $\mathrm{PhD}^{157}$, Jean-Eric

7 Tarride, $\mathrm{PhD}^{1589}$

8

91 Center for Health Economics and Policy Analysis (CHEPA). McMaster University, 10 Hamilton Ontario, Canada.

$11{ }^{2}$ Gilead Sciences México S. de R.L. de C.V.

$12{ }^{3}$ Center for Health Systems Research. National Institute of Public Health, Mexico

$13{ }^{4}$ ChB Department of Pathology and Molecular Medicine, Faculty of Health Sciences, 14 McMaster University, Hamilton, Ontario, Canada.

$15{ }^{5}$ Department of Health Research Methods, Evidence, and Impact (HEI), Faculty of Health

16 Sciences, McMaster University ON, Canada

$17{ }^{6}$ Biostatistics Unit, Father Sean O'Sullivan Research Centre, St Joseph's Healthcare, 18 Hamilton, ON, Canada

$19{ }^{7}$ Department of Medicine, McMaster University.

$20{ }^{8}$ McMaster Chair in Health Technology Management

$21{ }^{9}$ Programs for Assessment of Technology in Health (PATH), The Research Institute of St.

22 Joe's Hamilton, St. Joseph's Healthcare Hamilton

*Corresponding author: Amilcar Azamar-Alonso

Mail Address:

CRL 201, McMaster University 1280 Main St West Hamilton, Ontario, Canada 


\section{Patient characteristics and determinants of CD4 at diagnosis of HIV in Mexico from 2008 to 2017: a 10-year population-based study}

ABSTRACT (280 words- 350 allowed)

Background: Worldwide, around 37.9 million people are living with HIV, of which 220,000 live in Mexico. In 2007-2012 the Mexican government launched the National HIV program and there was a major change in HIV policies implemented in 2013-2018, when efforts focused on prevention, increase in early diagnosis and timely treatment. Thus, the objectives of this study were to identify the determinants of late HIV diagnosis (i.e. CD4 count less than 200 cells $/ \mathrm{mm}^{3)}$ in Mexico from 2008 to 2017 and to evaluate the impact of the 2013-2017 National HIV program.

Methods: Using patient level data from the SALVAR database, which includes $64 \%$ of the population receiving HIV care in Mexico, an adjusted logistic model was conducted. Main study outcomes were HIV late diagnosis which was defined as CD4 count less than 200 cells/mm3 at diagnosis.

Results: the study included 106,830 individuals newly diagnosed with HIV and treated in Mexican public health facilities between 2008 and 2017 (mean age: 33 years old, 80\% male). HIV late diagnosis decreased from $45 \%$ to $43 \%$ (P <0.001) between 2008-2012 and 20132017 (i.e. before and after the implementation of the 2013-2017 policy). Multivariable logistic regressions indicated that being diagnosed between 2013-2017 (odds ratio [OR]= $0.96[95 \%$ Confidence interval $[\mathrm{CI}]:[0.93,0.98])$ or in health facilities specialized in HIV $(\mathrm{OR}=0.64$ [95\% CI: 0.60, 0.69]) was associated with early diagnosis. Being male, older than 29 years old, diagnosed in Central East, the South region of Mexico or in high-marginalized locality increased the odds of a late diagnosis. 
1 Conclusions: The results of this study indicate that the 2013-2017 National HIV program in

2 Mexico has been marginally successful in decreasing the proportion of individuals with late 3 HIV diagnosis in Mexico.

4 Keywords: HIV, Late diagnosis, Mexican SALVAR.

5

6 [Word count 3,022 including heading and subheadings. excluding references, tables, 7 and figures]

8 


\section{BACKGROUND}

3 Worldwide, more than 37.9 million people are living with HIV (PLWH) of which around

4 220,000 live in Mexico (1,2). In Mexico and elsewhere, the number of individuals diagnosed

5 with HIV has increased during the last decade due to more transmission as well as disease

6 awareness and the implementation of programs aimed to identify people at the early stage of

7 the disease (3). In 2019, approximately 17,000 Mexicans were diagnosed with HIV, most of

8 them were male (85\%), between the ages of 25-39 years (70\%) and contracted HIV due to

9 sexual contact (71\%) (4). Recognizing the problem as a public health matter, the Mexican

10 government established twenty years ago different programs to improve HIV national

11 indicators and the overall health of PLWH. In the beginning, efforts were focused on

12 prevention for high risk populations (5), and the implementation of rapid testing aimed at

13 pregnant women (2). An important improvement in HIV policies happened in 2003 when the

14 Mexican government expanded the coverage of HIV treatment and care in public health

15 facilities to people who were unemployed and individuals from the informal sector $(6,7)$. In

16 2007, the National HIV program targeting prevention of HIV transmission in key high-risk

17 populations -e.g. men who have sex with men, sexual workers- was launched and was in

18 effect for 5 years (2,5). A major change in HIV policies in Mexico was observed in 2013

19 when the 2013-2018 National HIV program was implemented with the mandate to expand

20 efforts beyond the prevention of HIV transmission among high-risk populations to include

21 populations at a lower risk (e.g. young people and women) and to increase early diagnosis

22 and timely treatment (8). One of the key objectives of the 2013-2018 National HIV program

23 was to decrease the percentage of individuals diagnosed with a late HIV diagnosis to $30 \%$ in

24 2017. To support these efforts, the HIV budget also doubled and additional resources were 
1 allocated to improve HIV care across Mexico $(9,10)$. For example, the number of HIV

2 facilities outside of Mexico City increased from 49 in 2007 to 137 in 2017 (3,11).

3 Timely diagnosis and initiation of antiretroviral therapy are crucial to ensure optimal

4 health outcomes among PLWH (12). However very few studies have been conducted to

5 evaluate the impact of Mexican HIV policies on outcomes. For example, one study reported

6 that in 2012 (5 years after the implementation of 2007-2012 HIV national program), more

7 than half of patients died within six months after diagnosis, and the main factor associated

8 with death was a late diagnosis (13). More recent government reports have documented that

9 the percentage of individuals diagnosed with less than $200 \mathrm{CD} 4$ cells $/ \mathrm{mm}^{3}$ decreased from

$1050 \%$ to $40 \%$ between 2015 and $2018(14,15)$, suggesting a positive impact of the HIV policy

11 in Mexico. However, only one study has examined the predictors of late diagnosis in Mexico

12 using data from 2007 to 2014. While results indicate that men and older adults (more than 50

13 years old) were at a higher likelihood of late diagnosis (12) compared to the general

14 population, this situation may have changed following the modifications in HIV policies that

15 happened in Mexico after 2013. To better identify people at high-risk for a late diagnosis,

16 and to inform further policies and strategies in Mexico to reach these people early, the main

17 objectives of this study were to identify the determinants of late HIV diagnosis in Mexico

18 between 2008 and 2017 and to evaluate the impact of the 2013-2017 National HIV Program.

19 METHODS

20 Study design

21 The design was a retrospective population-based cohort study using Mexican administrative

22 health data from the antiretroviral therapy administration, logistics, and surveillance system

23 (Sistema de Administración, Logística y Vigilancia de Antirretrovirales - SALVAR for its

24 acronym in Spanish). 
Data source

2 The SALVAR database is an electronic system created in 2006 by the National Center for the

3 Prevention and Care of HIV/AIDS to manage the clinical information of PLWH enrolled in

4 the HIV/AIDS program led by the Mexican Ministry of Health (approximately $64 \%$ of all

5 PLWHs in Mexico). While SALVAR was developed in 2006, it was not until 2008 that it was

6 operational across Mexico. Currently, the system contains information on more than 172,000

7 Mexicans living with HIV (15).

8 Study population

9 The study population includes adults (18 years or older) diagnosed with HIV between 10 January $1^{\text {st }}, 2008$, and December $31^{\text {st }}$ of 2017 in health facilities affiliated to the Ministry of

11 Health. Pregnant women, children, people who are incarcerated, and people receiving 12 antiretroviral prophylaxis were excluded from the analyses. Individuals with incomplete 13 information on gender, age, date of diagnosis, and results of the first measurement of Viral 14 Load (VL) and CD4 were also excluded.

15 Study outcomes

16 The primary outcome of the study was HIV late diagnosis which was defined as CD4 count 17 less than 200 cells $/ \mathrm{mm}^{3}$ at the first measure reported in SALVAR. Secondary outcomes 18 included CD4 cell count at time of diagnosis, CD4 cell count stratified based on WHO 19 recommendations: less than $(<)$ 200, 200-349, 350-499 and, equal or more than $(\geq) 500$ 20 cells $/ \mathrm{mm}^{3}$ (16), and VL at time of diagnosis stratified as VL $\leq 100,000$ units by milliliters of 21 blood (u/ml) and more than 100,000 u/ml (17) for descriptive proposes. For CD4, a lower 22 limit of zero and an upper limit of 2,000 cells $/ \mathrm{mm}^{3}$ was established based on clinical literature $23(12,18,19)$. 
2 Age was described as a continuous variable reporting the mean and median, also age was 3 categorized in groups (18-29, 30-39, 40-49, 50-59, and $\geq 60$ years old). Gender was stratified

4 as male, female, and transgender. Characteristics related to health facilities were also 5 included. For the purpose of the study, Mexico was divided into five regions $(13,20)($ Central 6 West, Central East, Northwest, Northeast, and South) and Mexico City was also counted as 7 an additional region due its large population (25\% of Mexicans live in Mexico City) and 8 distinct structural characteristics. In addition, marginalization indices $(12,21)$ grouped into 9 three categories (high/ very high, medium and very low/low) were used to capture social and economic differences by locality of the health facilities where care is provided. Health

11 facilities in which diagnosis and care are provided were described in terms of 1) Hospitals and National Institutes that provides primary and specialty care in a tertiary level hospital; 2) Ambulatory Centers for Prevention and Attention for HIV/AIDS and Sexually Transmitted Infections (CAPASITS in Spanish) facilities which are specialized, stand-alone centers that provide ambulatory care for HIV and STI; and 3) Condesa, a specialized clinic for HIV 16 located in Mexico city and which provides HIV ambulatory care for more than 15,000 PLWH 17 in Mexico City.

\section{Statistical analysis}

19 Key characteristics of the study population were divided and compared in two periods 20 according to policies changes, between 2008-2012 and 2013-2017. Student t-test and Welch 21 test were presented for normally and non-normally distributed continuous variables while 22 Chi-square tests were used for categorical variables. Due to expected skewness of some 23 variables, mean values along with standard deviations (SDs) as well as median values and 24 interquartile ranges (IQR) were used to summarize continuous variables (e.g. age, CD4 
1 levels). Discrete variables were presented using percentages. Patients' and healthcare

2 facilities' characteristics as well as outcomes (i.e. CD4 and VL) were presented for the 3 periods of analysis to illustrate trends over time.

$4 \quad$ Logistic regressions were conducted to identify the determinants of late HIV diagnosis 5 (i.e. CD4 $<200$ cells $/ \mathrm{mm}^{3}$ ). All models were adjusted by the covariates mentioned above.

6 In addition, a dummy variable corresponding to the period when diagnosed (2008-2012; and

7 2013-2017) was used to estimate the impact of the 2013-2018 HIV policies implemented in

8 Mexico. To have a better understanding of the determinants of late HIV diagnosis before and

9 after the implementation of the National HIV program in 2013, separate models were 10 estimated for the period 2008-2012 and 2013-2017. Logistic models were reported using

11 Odds Ratios (OR) and associated confidence interval. Models' goodness of fit was evaluated 12 with Receiver Operating Characteristic (ROC) curves and C-statistic (22), where a C-statistic 13 value of 0.70 or greater indicates good discrimination.

\section{$14 \quad$ RESULTS}

15 Study population characteristics

16 From the initial 128,796 individuals included in the SALVAR database for the period 2008-

$172017,5,688$ were children or pregnant women, 13,510 did not have information on diagnosis,

18 CD4 counts or VL results' date, 1,842 patients did not have information about CD4 and VL, 1923 people were on prophylaxis, and 494 were people deprived of their liberty. After 20 excluding these groups (Figure 1), the study population consisted of 106,830 individuals.

21 Figure 1. Sample Flow for Analysis

22 
1 Table 1 summarizes the patients' characteristics at diagnosis over the period 2008-2017 and

2 for each of the two periods of the analysis (2008-2012 and 2013-2017). The median age of

3 the population was 31 years old $(\mathrm{IQR}=25,39)$ and $80 \%$ were males. Almost two thirds of the

4 study population were diagnosed in CAPASITS facilities, one third in the Central East region

5 and $94 \%$ in regions with low marginality index (less deprived areas). Most of the health

6 facilities were in regions of low marginalization index. Several changes were observed over

7 the two periods of analysis (i.e. 2008-2012 and 2013-2017). For example, the median age

8 decreased from 32 (IQR: 26, 40) to 31 (IQR: 25, 39) years old between 2008-2012 and 2013-

$92017(P<0.001)$ while the proportion of individuals aged 18 to 29 years of age at diagnosis

10 increased from $40 \%$ in the period $2008-2012$ to $45 \%$ in $2013-2017(P<0.001)$. During the

11 same period, the proportion of male individuals at diagnosis increased from $77 \%$ to $81 \%$

$12(P<0.001)$. More individuals were diagnosed in the South of Mexico over time $(P<0.001)$

13 and less in the Northwest region $(P<0.001)$. Table 1 provides the details.

14

15 Table 1. Summary Statistics and Patients' Characteristics at Diagnosis, 2008-2017

\begin{tabular}{lcccc} 
& Total & $\mathbf{2 0 0 8 - 2 0 1 2}$ & $\mathbf{2 0 1 3 - 2 0 1 7}$ & $\boldsymbol{P}$-value \\
\hline \hline Sample & 106830 & $47613(44.57 \%)$ & $59214(55.43 \%)$ & \\
Age & & & & \\
Mean (SD) & $33.13(10.43)$ & $33.55(10.34)$ & $32.80(10.48)$ & $<0.001$ \\
Median (IQR) & $31(25,39)$ & $32(26,40)$ & $31(25,39)$ & \\
\% & & & & \\
$18-29$ yo & 43.06 & 40.04 & 45.72 & \\
$30-39$ yo & 31.83 & 34.38 & 30.39 & \\
$40-49$ yo & 16.85 & 17.88 & 15.94 & $<0.001$ \\
$50-59$ yo & 6.04 & 5.92 & 6.14 & \\
$\geq 60$ yo & 1.8 & 1.79 & 1.81 & \\
\hline Gender (\%) & & & & \\
Male & 79.57 & 77.84 & 81.5 & $<0.001$ \\
Female & 19.66 & 21.74 & 18.09 & \\
Transgender & 0.41 & 0.40 & 0.41 & $<0.001$ \\
\hline Health facility (\%) & & & & \\
Hospital/ National Institute & 20.59 & 21.12 & 19.38 & $=$
\end{tabular}




\begin{tabular}{lccc} 
CAPASITS & 66.46 & 66.32 & 66.31 \\
Specialized clinics & 13.1 & 12.57 & 14.31 \\
\hline \hline Region (\%) & & & 17.27 \\
Mexico City & 16.85 & 16.68 & 31.14 \\
Central East & 30.89 & 31.60 & 13.18 \\
Central West & 13.10 & 13.61 & 11.84 \\
\hline Northeast & 13.10 & 13.89 & 8.39 \\
Northwest & 8.49 & 8.61 & 18.17 \\
South & 16.85 & 15.61 & 2.21 \\
\hline \hline Marginality Index (\%) & & 1.26 \\
High & 2.05 & 1.85 & 96.53 \\
Medium & 1.20 & 1.13 & \\
Low & 93.61 & 97.02 & \\
\hline SD: Standard Deviation. Yo: years old. IQR: Interquartile. CAPASITS: Ambulatory Centers for Prevention and Attention for \\
HIV/AIDS and Sexually Transmitted Infections in Spanish. \\
Source: Authors' creation with information of SALVAR
\end{tabular}

1

2 CD4 cells and Viral Load levels over time

3 Table 2 presents the data on CD4 and VL ( $\log 10)$ for the whole population over 2008 and

42017 and for each of the two periods of analysis (2008-2012 and 2013-2017). Overall, the

5 number of individuals with a late diagnosis $\left(C D 4<200\right.$ cells $/ \mathrm{mm}^{3}$ decreased significantly

6 from $45 \%$ in $2008-2012$ to $43 \%$ in $2013-2017(P<0.001))$. In parallel, the percentage of

7 individuals diagnosed with a VL>100,000 u/ml increased from $35 \%$ to $38 \%$ in the same

$8 \operatorname{period}(P<0.001)$.

9

10 Table 2. Summary Statistics for CD4 and Viral Load at Diagnosis

\begin{tabular}{ccccc} 
& Total & $\mathbf{2 0 0 8 - 2 0 1 2}$ & $\mathbf{2 0 1 3 - 2 0 1 7}$ & P-value \\
\hline \hline Sample & 106830 & 47616 & 59214 & \\
CD4 cells & & & & \\
Mean (SD) & $288(253)$ & $286(256)$ & $291(251)$ & $<0.001$ \\
Median (IQR) & $233(88,417)$ & $226(88,410)$ & $238(89,422)$ & \\
$\%$ & & & \\
$<200$ & & & & \\
$200-349$ & 44.93 & 45.58 & 43.8 & $<0.001$ \\
$350-499$ & 22.47 & 22.44 & 22.36 & 16.01 \\
$>=500$ & 15.91 & 14.84 & 17.83 &
\end{tabular}




\begin{tabular}{ccccc} 
Mean (SD) & $4.28(1.39)$ & $4.15(1.42)$ & $4.38(1.36)$ & $<0.001$ \\
Median (IQR) & $4.67(3.56,5.27)$ & $4.59(3.13,5.19)$ & $4.73(3.80,5.32)$ & \\
$\%$ & & & & \\
$\leq 100,000 \mathrm{u} / \mathrm{ml}$ & 62.72 & 64.76 & 61.35 & $<0.001$ \\
$>100,000 \mathrm{u} / \mathrm{ml}$ & 37.44 & 35.24 & 38.65 & \\
\hline \multicolumn{2}{l}{ SD: Standard Deviation. IQR: Interquartile. Source: Authors' creation with information of SALVAR } \\
\hline
\end{tabular}

1

2 Figure 2 presents over time the proportion of individuals diagnosed with CD4 <200

3 cells $/ \mathrm{mm}^{3}$ according to the type of facilities where they were diagnosed. Considering both

4 periods, less individuals were diagnosed with a late diagnosis in Condesa compared to the

Figure 2. Percentage of individuals with a late diagnosis $\left(\mathrm{CD} 4<200\right.$ cells $\left./ \mathrm{mm}^{3}\right)$ by health facility and year

\section{[INSERT FIGURE 2]}

Source: Authors' creation with information of SALVAR

\section{Determinants of late diagnosis}

The results of the multivariable logistic regression for CD4 at diagnosis are shown in Table 3. For CD4, being diagnosed during the period 2013-2017 compared to the previous period was associated with lower odds of late diagnosis (0.96 [95\% CI: 0.93, 0.98]). Other factors associated with lower odds of late diagnosis were being diagnosed at CAPASITS facilities (0.89 [95\% CI: $0.86,0.93])$ or specialized clinics (0.64 [95\% CI: 0.60, 0.69]), compared to Hospitals. The variables that significantly increased the odds of a late diagnosis were being male compared to female $(1.26$ [95\% CI: 1.24, 1.32]), being older than 29 years old (1.84 [95\% CI: 1.79, 1.90], 2.24 [95\% CI: 1.79, 1.90], 2.42 [95\% CI: 2.30, 2.56], 2.34 [95\% CI: $2.13,1.31]$ respectively for each age group), being diagnosed in a Central East (1.16 [95\% 
1 CI: $1.08,1.26])$ or South region $(1.21$ [95\% CI: 1.12, 1.31]) compared to Mexico City, and

2 in a high marginalized locality $(1.23$ [95\% CI: 1.12, 1.35]). However, as shown by the

3 stratified analyses by time period (Table 3), being diagnosed outside Mexico City became a

4 factor associated with lower odds during the period 2013-2017, while it increased the odds

5 of a late diagnosis when diagnosed before 2013. The odds associated with a diagnosis at a

6 later age were also greater for the period 2013-2017. Table 3 provides the details including

7 the coefficients difference test across periods (Hausman test). As shown in these tables the C

$8 \quad$ statistics in all models were below 0.70 .

9

10 Table 3. Multivariate Logistic Regression for CD4 at Diagnosis, 2008-2017

\begin{tabular}{|c|c|c|c|}
\hline Variable & $\begin{array}{c}\text { OR } \\
\text { CD4 }(1:<200 \\
\left.\text { cells } / \mathrm{mm}^{3}\right) \\
\text { All periods }\end{array}$ & $\begin{array}{c}\text { OR } \\
\text { CD4 }(1:<200 \\
\left.\text { cells } / \mathrm{mm}^{3}\right) \\
2008-2012 \\
\end{array}$ & $\begin{array}{c}\text { OR } \\
\text { CD4 }(1:<200 \\
\left.\text { cells/mm }{ }^{3}\right) \\
2013-2017 \\
\end{array}$ \\
\hline \multicolumn{4}{|c|}{$\begin{array}{l}\text { Period of diagnosis (reference } \\
\text { 2008-2012) }\end{array}$} \\
\hline 2013-2017 & $\begin{array}{c}0.96^{* *} \\
(0.93,0.98)\end{array}$ & & \\
\hline \multicolumn{4}{|c|}{ Gender (reference female) } \\
\hline Male & $\begin{array}{c}1.28 * * \\
(1.24,1.32)\end{array}$ & $\begin{array}{c}1.33 * * \\
(1.27,1.40)\end{array}$ & $\begin{array}{c}1.26 * * \\
(1.20,1.32)\end{array}$ \\
\hline Transgender & $\begin{array}{c}0.94 \\
(0.77,1.15)\end{array}$ & $\begin{array}{c}1.09 \\
(0.81,1.47)\end{array}$ & $\begin{array}{c}0.84 \\
(0.64,1.10)\end{array}$ \\
\hline \multicolumn{4}{|c|}{ Age group (reference 18-29) } \\
\hline $30-39$ & $\begin{array}{c}1.84 * * \\
(1.79,1.90)\end{array}$ & $\begin{array}{c}1.65 * * \\
(1.59,1.73)\end{array}$ & $\begin{array}{c}2.00 * * \\
(1.92,2.08)\end{array}$ \\
\hline $40-49$ & $\begin{array}{c}2.24 * * \\
(1.79,1.90)\end{array}$ & $\begin{array}{c}1.87 * * \\
(1.78,1.97)\end{array}$ & $\begin{array}{c}2.59 * * \\
(2.47,2.72)\end{array}$ \\
\hline $50-59$ & $\begin{array}{c}2.42 * * \\
(2.30,2.56)\end{array}$ & $\begin{array}{c}1.97 * * \\
(1.82,2.1)\end{array}$ & $\begin{array}{c}2.83 * * \\
(2.63,3.04)\end{array}$ \\
\hline$>60$ & $\begin{array}{c}2.34 * * \\
(2.13,2.57)\end{array}$ & $\begin{array}{c}1.79 * * \\
(1.56,2.05)\end{array}$ & $\begin{array}{c}2.87 * * \\
(2.53,3.25)\end{array}$ \\
\hline \multicolumn{4}{|c|}{ Region (Mexico City) } \\
\hline Central East & $\begin{array}{c}1.16^{*} \\
(1.08,1.26)\end{array}$ & $\begin{array}{c}1.50 * * \\
(1.34,1.67)\end{array}$ & $\begin{array}{c}0.90 \\
(0.80,1.01)\end{array}$ \\
\hline Central West & $\begin{array}{c}0.89 * \\
(0.82,0.96)\end{array}$ & $\begin{array}{c}1.16^{*} \\
(1.04,1.29)\end{array}$ & $\begin{array}{c}0.68 * * \\
(0.61,0.76)\end{array}$ \\
\hline Northwest & $\begin{array}{c}0.97 \\
(0.89,1.05)\end{array}$ & $\begin{array}{c}1.28 * * \\
(1.14,1.43)\end{array}$ & $\begin{array}{c}0.74 * * \\
(0.66,0.86)\end{array}$ \\
\hline Northeast & $\begin{array}{c}1.05 \\
(0.97,1.15)\end{array}$ & $\begin{array}{c}1.47 * * \\
(1.30,1.66)\end{array}$ & $\begin{array}{c}0.77 * * \\
(0.68,0.86)\end{array}$ \\
\hline South & $1.21 * *$ & $1.55^{* *}$ & 0.94 \\
\hline
\end{tabular}




\begin{tabular}{|c|c|c|c|}
\hline \multicolumn{4}{|c|}{$\begin{array}{l}\text { Type of health facility (reference hospital/National } \\
\text { Institute) }\end{array}$} \\
\hline CAPASITS & $\begin{array}{c}0.89 * \\
(0.86,0.93)\end{array}$ & $\begin{array}{c}0.84 * * \\
(0.80,0.89)\end{array}$ & $\begin{array}{c}0.93 * \\
(0.89,0.99)\end{array}$ \\
\hline Specialized clinics & $\begin{array}{c}0.64 * * \\
(0.60,0.69)\end{array}$ & $\begin{array}{c}0.70 * * \\
(0.63,0.78)\end{array}$ & $\begin{array}{c}0.56^{* *} \\
(0.50,0.62)\end{array}$ \\
\hline \multicolumn{4}{|c|}{$\begin{array}{l}\text { Index of marginalization (reference } \\
\text { low) }\end{array}$} \\
\hline Medium & $\begin{array}{c}1.05 \\
(0.93,1.18)\end{array}$ & $\begin{array}{c}0.90 \\
(0.75,1.08)\end{array}$ & $\begin{array}{c}1.17 * * \\
(1.00,1.37)\end{array}$ \\
\hline High & $\begin{array}{c}1.23 * * \\
(1.12,1.35)\end{array}$ & $\begin{array}{c}0.99 \\
(0.86,1.15)\end{array}$ & $\begin{array}{c}1.43 * * \\
(1.27,1.62)\end{array}$ \\
\hline Observations & 106,830 & 47,616 & 59,214 \\
\hline C-Statistics & 0.6158 & 0.6009 & 0.6165 \\
\hline
\end{tabular}

3 By analyzing 10 years of data this study has provided new information to better understand

4 the characteristics of the individuals diagnosed with HIV in Mexico between 2008 and 2017

5 and the impact of HIV policies implemented since 2007. Compared to the 2008-2012 period,

6 more individuals were diagnosed at a younger age, less women were identified HIV positive,

7 and more individuals were diagnosed in the South of Mexico in the period 2013-2017. Our

8 univariate and multivariable analyses indicate that the actions implemented during the period

$9 \quad 2013-17$ to reduce late diagnosis of HIV (12) in Mexico were marginally successful as the

10 odds of a late diagnosis decreased by $4 \%$ during that time period compared to 2008-2012.

11 However, still $42 \%$ of Mexicans are being diagnosed with CD4 $<200$ cells $/ \mathrm{mm}^{3}$ compared to

12 a governmental objective of $30 \%$ late diagnosis in 2017 (8). Our stratified analyses also

13 showed a strong regional effect during the period 2013-2017, with living outside of Mexico

14 City decreased the odds of a late diagnosis. These results could be explained by an increase

15 in HIV health facilities (i.e. CAPASITS) outside Mexico City (from 49 in 2007 to 137 in

16 2017) $(3,11)$ and the change from a decentralized to an integrated approach to HIV treatment 
1 and care in all HIV facilities in Mexico (8) as a result of the implementation of the 2013-17

2 National plan.

3 It is difficult to compare our results to other studies conducted in Mexico due to different

4 study designs or period of analysis. However our results are similar to the findings of

5 Carrizosa et al. (23) who reported a late diagnosis rate of $43.2 \%$ in 2010 . Findings are also

6 aligned with the results presented by Hernandez Romieu et al.(12) who reported using data

7 from 2007 to 2014 that being male and being older increased the odds of a late diagnosis.

8 Compared to this study, we also showed that being diagnosed in CAPASITS or Condesa

9 reduced the risk of a late diagnosis compared to being diagnosed in non-specialized HIV

10 hospitals. Another study among women using 2012-13 data from 4 clinics in Mexico also

11 found that being older increased the risk of late diagnosis (24). On the other hand, while we

12 found that being male increased the risk of a late diagnosis, a study conducted in 2011-12 in

13 Mexico city, reported that women were more likely to be diagnosed later given that they have

14 no suspicious of risk of infection due to their cultural and social disadvantage $(11,24)$. These

15 results could indicate that the prevention programs and early diagnosis policies no longer

16 exclusively target high-risk populations (men who have sex with men and transgender

17 population) and are consistent with the objectives established in the National Program in

182013 (8). Similarly, belong to the younger group represents a protective factor for a late

19 diagnosis, which could be explained for a higher perception of risk and, therefore routinely

20 testing, or because the treatment is free, even unemployed and unsecured young people could

21 access care $(12,21)$. Compared to the studies previously conducted in Mexico around HIV,

22 our study provides new information as we also evaluated the impact of the 2013 National

23 Specific Action program. We also showed that determinants of late diagnosis changed before 
1 and after the implementation of the 2013-2017 HIV policies and found important differences

2 at the regional level.

3 When interpreting the results a few limitations should be noted. First it was assumed that

4 the $1^{\text {st }}$ measure observed in SALVAR database for CD4 and VL was the measure associated

5 with the diagnosis of HIV, which may not be always accurate. While we conducted

6 regression analyses to identify the determinants of late diagnosis and VL levels, we were

7 constrained by the list of variables available in the database and there may be unmeasured

8 confounders such as the increase in number of health facilities and distribution across

9 Mexican regions or the type of population reaching heath care. This could explain why our

10 logistic regression models had moderate discrimination. Additionally, SALVAR does not

11 account for the whole PLWH in Mexico, only for those registered in the Ministry of Health.

12 Additionally, given the design of the models, we cannot claim that policy was completely

13 responsible of changes in levels of late diagnosis, these could be also part of an increasing

14 awareness, and a reduction on discrimination and stigma. However, we adjust the model by

15 possible trend with a period variable and the study represents a first approach to associate

16 measurable factors with late diagnosis and provide evidence for further research. Despite

17 these limitations, our study has several strengths including the use a population-based cohort

18 representing approximately $64 \%$ of the population receiving HIV care in Mexico. This is also

19 the first study using and analyzing data later than 2014.

20 As it was mentioned before, some hypotheses can be formulated with all the information

21 presented. We have identified key indicators, trends, and predictors of CD4 and VL levels at

22 diagnosis to inform about the HIV/AIDS epidemic in Mexico. Although we observed a

23 decrease in the number of individuals with a late diagnosis after the implementation of the

242013 National Specific program, this proportion is still high regarding the objective set in the 
1 2013-2018 national plan (30\%), and efforts should continue to improve HIV outcomes at

2 diagnosis and reduce HIV transmission. Future research is also required to continue to

3 evaluate the effectiveness of prevention programs such as increasing the HIV diagnosis rates

4 and reaching to broader populations for early detection, Furthermore, the information from

5 SALVAR database could be analyzed to identify time from diagnosis to treatment, and what

6 can be improved to ensure access to antiretroviral therapy through the universal access

7 program in Mexico. Finally, additional research should be made to measure the specific

8 differences in economic resources and possible improvements to lead changes in national

9 programs to reduce inequalities across health facilities and Mexican regions.

10

11

12

13

14

1

\section{CONCLUSIONS}

The results of this study indicate that the proportion of individuals with a late HIV diagnosis decreased marginally following the National HIV program implemented in 2013 in Mexico. However, the proportion of late HIV diagnosis remains much above the proposed levels in the National Specific Action Plan 2013-2018. Analyzing those factors that identify high-risk populations for a late diagnosis could expedite the achievement of policy objectives and improve national indicators of HIV in Mexico. Therefore, more efforts should be allocated to improve early detection and treatment of HIV.

.

0




\section{$3 \quad$ List of abbreviations}

$4 \quad$ PLWH -- People living with HIV

5 SALVAR -- Antiretroviral therapy administration, logistics, and surveillance system in 6 Spanish.

$7 \quad$ VL -- Viral Load

8 CAPASITS -- Ambulatory Centers for Prevention and Attention for HIV/AIDS and Sexually

9 Transmitted Infections in Spanish

10 SDs -- Standard deviations

11 IQR -- Interquartile

12 OR -- Odds ratios

\section{References}

1. UNAIDS. UNAIDS DATA 2019 [Internet]. Report No.: JC2959E. Available from: https://www.unaids.org/sites/default/files/media_asset/2019-UNAIDS-data_en.pdf

2. Hernández-Ávila JE, Palacio-Mejía LS, Hernández-Romieu A, Bautista-Arredondo S, Sepúlveda Amor J, Hernández-Ávila M. Implementation and Operational Research: Effect of Universal Access to Antiretroviral Therapy on HIV/AIDS Mortality in Mexico 1990-2011. JAIDS J Acquir Immune Defic Syndr [Internet]. 2015 Jul [cited 2019 Dec http://content.wkhealth.com/linkback/openurl?sid=WKPTLP:landingpage $\& a n=00126$ 334-201507010-00020

24 3. CENSIDA. Panorama de la respuesta nacional al VIH. Mexico; 2015.

4. CENSIDA. Vigilancia Epidemiológica de casos de VIH/SIDA en México Registro Nacional de Casos de SIDA Actualización al 11 de noviembre del 2019 [Internet]. https://www.gob.mx/cms/uploads/attachment/file/513720/RN_D_a_Mundial_sida_20 
5. Rangel Flores YY. Narrativas del riesgo respecto del VIH/sida en México. De letal a crónica y del estigma a los derechos humanos. Rev Col San Luis. 2015;9.

6. CSG. Guía de referencia rápida. Tratamiento antiretroviral del paciente adulto con infección por VIH [Internet]. Ciudad de México: CENETEC; 2009. Report No.: IMSS245-09. Available from: http://www.cenetec.salud.gob.mx/descargas/gpc/CatalogoMaestro/24509_Antirretrovirales_adultos/IMSS-245-

09_ANTIRETROVIRALES_EN_ADULTOSRR.pdf

7. CSG. Guía de manejo antirretroviral de las personas con VIH. Actualización [Internet]. 2019. Available from: https://www.gob.mx/cms/uploads/attachment/file/470115/Fragmento_Gu_a_de_Mane jo_ARV.pdf

8. Secretaría de Salud. Programa de Acción Específico Respuesta al VIH, Sida e ITS 20132018 [Internet]. 2013. Available from: http://www.censida.salud.gob.mx/descargas/acerca/PAE_2013_2018_AUTORIZADA .pdf

9. Secretaría de Gobernación. Diario Oficial de la Federación. Presupuesto de egresos. 2012.

10. Secretaría de Gobernación. Diario Oficial de la Federación. Presupuesto de Egresos. 2014.

11. Mugavero MJ, Castellano C, Edelman D, Hicks C. Late Diagnosis of HIV Infection: The Role of Age and Sex. Am J Med [Internet]. 2007 Apr [cited 2019 Dec 28];120(4):370-3. Available from: https://linkinghub.elsevier.com/retrieve/pii/S0002934306006760

12. Hernández-Romieu AC, del Rio C, Hernández-Ávila JE, Lopez-Gatell H, Izazola-Licea JA, Uribe Zúñiga P, et al. CD4 Counts at Entry to HIV Care in Mexico for Patients under the "Universal Antiretroviral Treatment Program for the Uninsured Population," 2007-2014. Pacheco AG, editor. PLOS ONE [Internet]. 2016 Mar 30 [cited 2019 Dec 25];11(3):e0152444. Available from: https://dx.plos.org/10.1371/journal.pone.0152444

13. Silverman-Retana O, Bautista-Arredondo S, Serván-Mori E, Lozano R. Mortalidad temprana por sida en México durante el periodo 2008-2012. Salud Publica Mex. 2015;57(2):S119-26. 
14. CENSIDA. Boletín de atención integral de personas con VIH 2015 [Internet]. 2015. Available from: https://www.gob.mx/cms/uploads/attachment/file/60983/Boletin_Nal_CENSIDA_AT _IN_oct_dic2015_2.pdf

15. CENSIDA. Boletín de atención integral de personas con VIH 2018 [Internet]. 2018. Available from: https://www.gob.mx/cms/uploads/attachment/file/513720/RN_D_a_Mundial_sida_20 19.pdf

16. WHO case definitions of HIV for surveillance and revised clinical staging and immunological classification of HIV-related disease in adults and children. Geneva: World Health Organization; 2007.

17. Wood E, Hogg RS, Yip B, Harrigan PR, Montaner JSG. Using baseline CD4 cell count and plasma HIV RNA to guide the initiation of highly active antiretroviral therapy. Rev Investig Clínica. 2004;56(2):232-6.

18. van Dorp $\mathrm{CH}$, van Boven $\mathrm{M}$, de Boer RJ. Immuno-epidemiological Modeling of HIV1 Predicts High Heritability of the Set-Point Virus Load, while Selection for CTL Escape Dominates Virulence Evolution. Regoes RR, editor. PLoS Comput Biol [Internet]. 2014 Dec 18 [cited 2019 Dec 26];10(12):e1003899. Available from: http://dx.plos.org/10.1371/journal.pcbi.1003899

19. Smith MK, Rutstein SE, Powers KA, Fidler S, Miller WC, Eron JJ, et al. The Detection and Management of Early HIV Infection: A Clinical and Public Health Emergency. JAIDS J Acquir Immune Defic Syndr [Internet]. 2013 Jul [cited 2019 Dec 26];63:S187_ 99. Available from: http://content.wkhealth.com/linkback/openurl?sid=WKPTLP:landingpage \&an=00126 334-201307012-00015

20. Bautista-Arredondo S, Colchero MA, Romero M, Conde-Glez CJ, Sosa-Rubí SG. Is the HIV Epidemic Stable among MSM in Mexico? HIV Prevalence and Risk Behavior Results from a Nationally Representative Survey among Men Who Have Sex with Men. Wainberg M, editor. PLoS ONE [Internet]. 2013 Sep 5 [cited 2019 Dec 26];8(9):e72616. Available from: https://dx.plos.org/10.1371/journal.pone.0072616

21. Crabtree-Ramírez B, Caro-Vega Y, Belaunzarán-Zamudio F, Sierra-Madero J. High prevalence of late diagnosis of HIV in Mexico during the HAART era. Salud Publica Mex. 2012;54:506-14.

22. Yang S, Berdine G. The receiver operating characteristic (ROC) curve. Southwest Respir Crit Care Chron [Internet]. 2017 May 5 [cited 2019 Dec 26];5(19):34. Available 
1

from:

http://www.pulmonarychronicles.com/index.php/pulmonarychronicles/article/view/39 1

23. Carrizosa CM, Blumberg EJ, Hovell MF, Martinez-Donate AP, Garcia-Gonzalez G, Lozada R, et al. Determinants and Prevalence of Late HIV Testing in Tijuana, Mexico. AIDS Patient Care STDs [Internet]. 2010 May [cited 2019 Dec 28];24(5):333-40. Available from: http://www.liebertpub.com/doi/10.1089/apc.2009.0138

24. Martin-Onraët A, Volkow-Fernández P, Alvarez-Wyssmann V, González-Rodríguez A, Casillas-Rodríguez J, Rivera-Abarca L, et al. Late Diagnosis Due to Missed Opportunities and Inadequate Screening Strategies in HIV Infected Mexican Women. AIDS Behav [Internet]. 2017 Feb [cited 2019 Dec 29];21(2):505-14. Available from: http://link.springer.com/10.1007/s10461-016-1560-1

\section{.}

(1)

5

6

7

8

9

0

1

2

3

4

5

6

7

8

9




\section{Declarations}

2 Ethics approval and consent to participate

3 We used secondary data. Analyzed data is from an anonymized database. Authors have not

4 contact with participants or their sensitive information such as name or address or any other

5 data that could identified them. Authors received consent for the use of the SALVAR data

6 set

$7 \quad$ Consent for publication

8 We used secondary data. Authors have not contact with participants or their specific

9 information such as name or address. Authors received consent for the publication of results

10 derived from the SALVAR data set.

11 Availability of data and materials

12 The data that supports the findings of this study are available from SALVAR and

13 CENSIDA Mexico, but restrictions apply to the availability of these data, which were used

14 under license for the current study, and so are not publicly available. Data are however

15 available from the authors upon reasonable request and with permission of SALVAR and

16 CENSIDA Mexico.

17 Competing interests

18 This study is part of AA PhD thesis. AA declares that he works full-time for Gilead Sciences

19 Mexico S. de R.L. de C.V. AA declares that he did not receive any financial support from

20 the firm to perform the analysis. The information contained in all data set was not used for

21 the firm's benefit, promotion or strategies. The analysis we are presenting do not intend to

22 promote or recommend any of the products mentioned in the paper.

23 The other authors have no conflicts of interest to declare.

$24 \quad$ Funding

25 Authors have no source of funding to declare.

26 Authors' contributions

27 All authors have contributed to the conception and design of the analysis; data; drafting and 28 reviewing of the manuscript; and approval of the final version.

- AA: Conception and design of the analysis, data analysis, drafting and reviewing of the manuscript

- JET: Conception and design of the analysis, data analysis review, drafting and reviewing of the manuscript, and approval of the final version. 
11 The authors acknowledge to the Center for Aids Prevention and Control in Mexico 12 (CENSIDA) the authorization to use the information for the analysis performed.

13 AA acknowledges the financial support of the Consejo Nacional de Ciencia y Tecnología 14 (CONACYT) to carry out his PhD studies. 
Figures

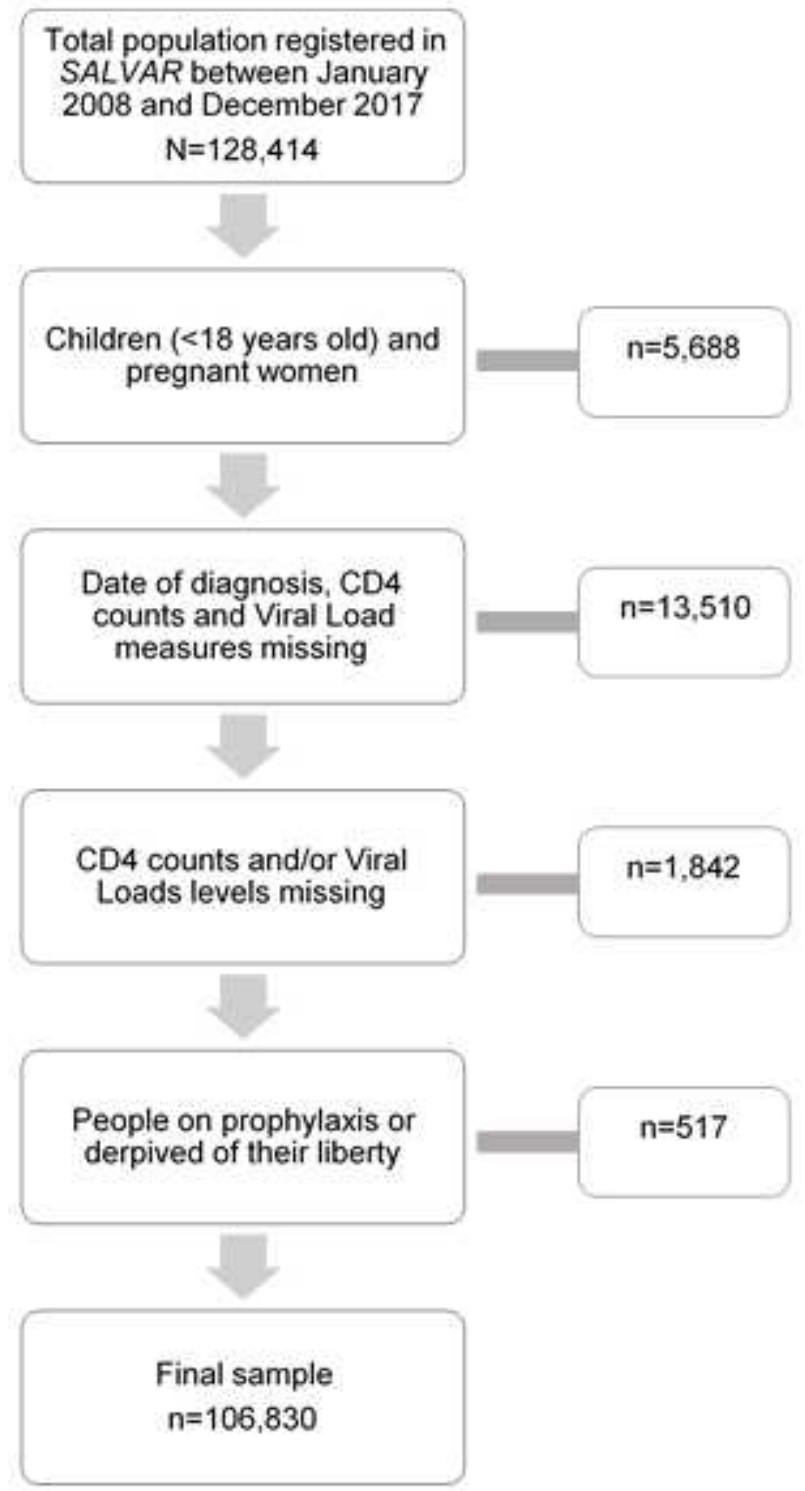

Figure 1

Sample Flow for Analysis. SALVAR: Sistema de Administración, Logística y Vigilancia de Antirretrovirales - SALVAR for its acronym in Spanish 


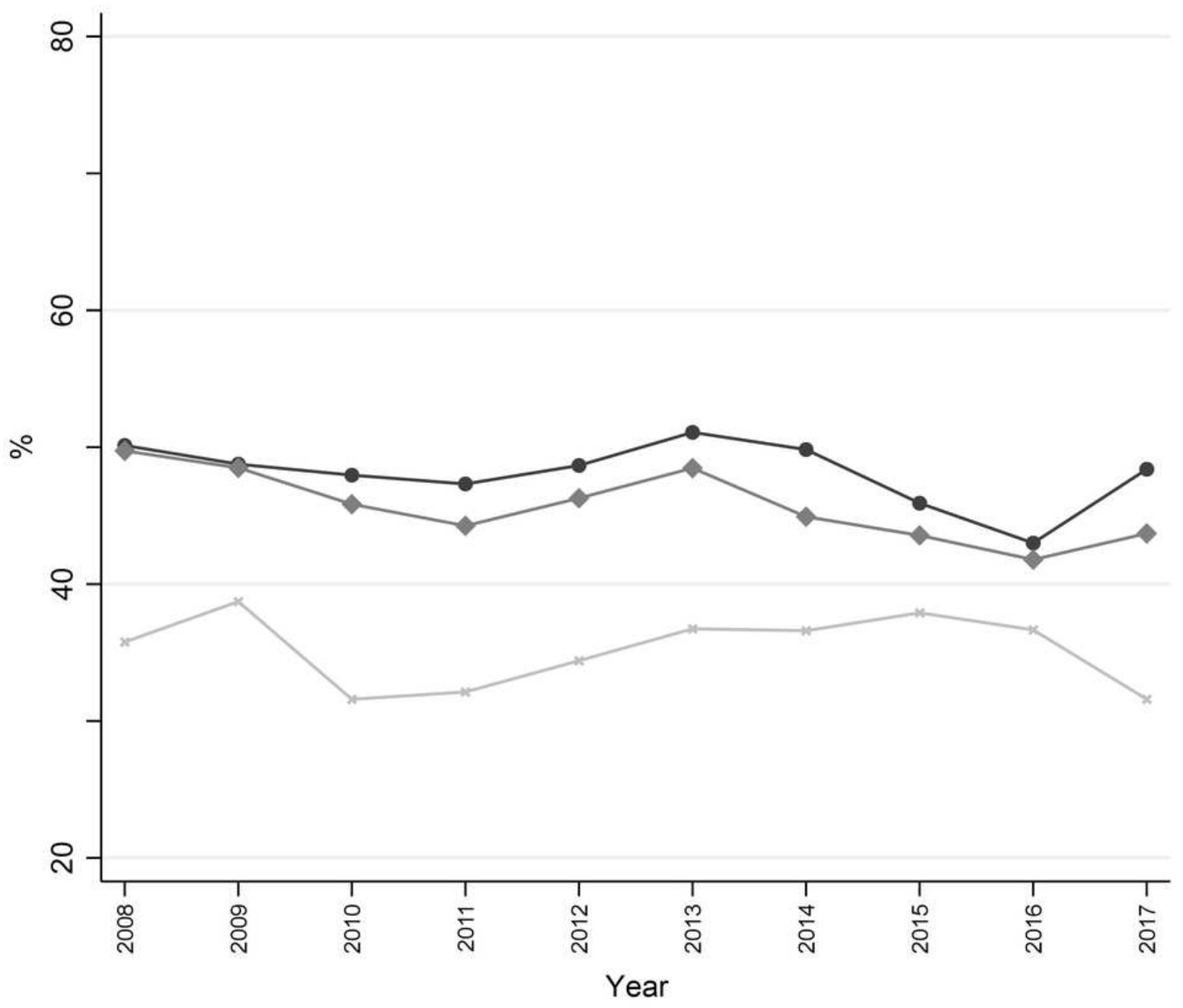

- Hospital/Institute

$\rightarrow$ CAPASITS

" Specialized clinic

Figure 2

Percentage of individuals with a late diagnosis (CD4 < 200cells $/ \mathrm{mm} 3)$ by health facility and year. Source: Authors' creation with information of SALVAR 